\title{
African Agricultural Development: the EEC's new role
}

\author{
Michael Lipton
}

\section{The 'Strategic' Approach}

The apparent agricultural failure of most African developing countries, especially their failure to increase food output per person, has led to a great flowering of 'strategic' proposals. The World Bank's plan for 'accelerated development', known as the Berg Report, advocates not only a sharp rise in the proportion of public outlays (and of international aid) that supports private African agriculturists, but also sharp shifts of the domestic terms of trade in their favour, and heavy concentration on export crops [World Bank 1982a]. The OAU's 'Lagos plan of action', like its offspring in the work of the Southern African Development Coordinating Committee, is orientated to the replacement of food imports, but despite much stress upon agriculture's 'priority' seeks aid above all for new publicly-owned transport links and industrial producers; both emphases might help farmers indirectly, but both are geared primarily towards greater political independence, and towards securing Africa's share in 'targets' set by UNCTAD for growing Third World proportions of industrial production [OAU 1981].

These two central strategies are moderately and intelligently presented. Much of their content, too, is indisputable: prices turned harshly against farmers [World Bank 1982a] and increasingly massive reliance upon food imports [OAU 1981] are incompatible with sustained agricultural progress. Yet, although the OAU and Bank expository documents are filled with gestures of mutual respect and even agreement, they sound a little like a somewhat tired, and not very Afrocentric, re-run of the Latin American development debates of 1957-64. These debates set publiclysponsored, import-substituting development in a planned economy against privately-managed, exportpromoting development in an open economy. ${ }^{1}$ The needs of agriculturists, especially of smallholders in Africa, easily go unheard beneath the clash; for it is grand, ideological, and essentially industry-orientated. The French radicals of 1968 proclaimed 'Ni Marx ni Jésus'; does broadly-based and efficient agricultural growth in Africa require 'Ni Berg ni Lagos"?

${ }^{1}$ The two opposing views were both well argued by Raoul Prebisch in, respectively [1959] and [1964].
Two other strategies, now in the course of being formulated, may hold out more prospects for meeting the specific needs of African farmers. The first strategy is implicit in the Charter of the International Fund for Agricultural Development (IFAD). The Charter directs IFAD to use its funds mainly to meet the food requirements of the poorest people in the poorest developing countries. IFAD, therefore, is almost bound to spotlight the great mass of African subsistence producers. In contrast to Asia, it is these and not 'landless labourers' (rural or urban) who form the great bulk of Africa's potentially hungry poor. They are mostly too small to be reached by the World Bank's 'smallholder' strategy, with its emphasis (initially at least) on producers and areas that seem more promising and progressive in the existing state of techno-economic knowledge. Also, most subsistence mini-farmers are insufficiently integrated into the urban economy to provide surpluses for it, and therefore do not appeal to the industrialising strategists of Lagos. IFAD could provide important guidelines, and funds, for development aimed at this large, poor group.

The other new approach stems from the increasing disillusionment of the Nordic and EEC aid donors with piecemeal rural activity in Africa. This disillusionment covers not only project aid (especially if it is 'integrated' across activities involving several weakly-coordinated ministries), but also food aid, which is increasingly seen as encouraging recipient governments to delay attention to agriculture. As an alternative, Nordic and EEC donors are seeking particular ways to help African countries to develop, not specific projects or aid requests, but a) total strategies for allocating resources, by private incentives and/or public action, towards rural activity; and b) policy, planning and implementation machinery (and human capacity) to make, change, and carry out such strategies for themselves in future. The Swedish aid agency, SIDA, has undertaken a series of 'rural-sector strategy missions' in East African countries. And the new head of EEC's Directorate General for Development (DG 8), Commissioner Edgard Pisani, having expressed deep doubts about existing EEC food and project aid, is seeking to 
reconstruct the substantial (and largely African) EDF programme increasingly around a series of 'food strategies', to eliminate undernutrition and fooddependency in a defined time-horizon [COM (82) 640]. Such strategies are, of course, to be developed by the countries themselves, with technical assistance only if they want it. The first four 'strategies' are being proposed by Kenya, Mali, Zambia and Rwanda.

All this is reminiscent of the World Bank's shift from project overview to 'policy dialogues', a shift designed to improve the Bank's impact on national development patterns. Like that shift, the 'rural strategy' approach is partly a recognition that normally a single aid project has far less effect on total (or rural) development than, say, policy on prices or personnel. Indeed, aid in support of any particular project may merely displace government support for the same project, so that the aid is effectively supporting the marginal, least-important government activity: what Hans Singer calls the 'fungibility problem'. Partly, too, the move towards national strategy-building and policy dialogue is a response to donors' resource scarcity; advice is cheaper than aid projects. ${ }^{2}$ More positively, however, a real case exists for this new emphasis. Rural and other development strategies, as attempted by developing countries or as advocated by funding agencies, are too prone to changing fashions. Both the EEC and its African associates need a series of medium-term, country-specific plans to achieve defined goals. ${ }^{3}$ In that context, the Pisani concept of country-by-country 'food strategies' may well be more tangible and specific than SIDA's search for comprehensive 'rural development strategies'. The goal of removing undernutrition in a specified timeframe is attractive, definable, and often attainable. This article seeks to clarify some of the issues and requirements facing any EEC programme to assist African countries in developing 'food strategies'.

Five main issues are considered, each very briefly. First, any strategies to end undernutrition in Africa need to examine its scale, nature and causes (next section). Second, to design any such strategy, based either on food-based agriculture or on trade, African and EEC planners could benefit from, and indeed may require, some tolerably reliable data (third section). Third, a national strategy for food-based agriculture has to select a 'mix' between approaches based on generalised price-incentives, on inputs of current and capital resources, on efforts to change the agricultural output-mix, on the rural 'surround', and on research, development and spread of new technologies (fourth section). Fourth, there are linked choices to be made

\footnotetext{
${ }^{2}$ But is advice less likely to be accepted as accompanying project aid becomes scarcer?

${ }^{3}$ This does not imply directive or comprehensive planning; indicative planning, with price incentives, is an alternative way to achieve such goals.
}

between big and small units of activity, and between labour-intensity and capital-intensity (fifth section). Finally and crucially, there are questions about the EEC itself: can its 'project cycle', country programming, related trade policy enable it to follow through its own commitments to support countryspecific food strategies, or to help African states to develop and implement such strategies (last section)?

This article will concentrate on points of fairly fundamental, though I hope constructive, criticism. It should, however, be recorded that the 'food strategy' approach - if it can survive the resource shortage, and the objections of some politicians in the EEC - will constitute an enormous advance on earlier EEC approaches to its relationship with the ACP states.

\section{Scale, Nature and Causes of Undernutrition in Africa}

The evidence increasingly suggests that - while unpleasant, even painful, hunger is widespread dangerous or damaging undernutrition, due to inability to afford enough food, is confined to 10-15 per cent of populations in African and Asian lowincome countries. ${ }^{4}$ Undernutrition therefore does not threaten all of the 40-50 per cent of such populations who are classified as 'in poverty'. ${ }^{5}$ Most such people are indeed often miserable, and deprived of basic needs such as health care, shelter, and school; but only the 10-15 per cent who are ultra-poor require a strategy of 'food (or income-to-buy-food) first' as a precondition for enjoying the fruits of development. ${ }^{6}$ Elsewhere I review the complex but increasingly massive evidence for this proposition, but, in view of its importance to the EEC in helping ACP countries to design a 'food strategy', the three main lines of reasoning must be indicated here.

Dietary energy ('calorie') requirements may be overstated, for five reasons. First, the standard FAO/WHO requirements for average Western persons appear to be considerably too high, supporting, for example, the dietary build-up and

\footnotetext{
${ }^{4} \mathrm{It}$ is increasingly agreed that food shortage (scarce calories), not food structure (eg too few proteins), is the main medium by which poverty causes undernutrition.

${ }^{5}$ References and evidence for this and other remarks in this section will appear in the author's forthcoming World Bank Staff Working Paper [1983], Poverty, Undernutrition and Hunger.

${ }^{6}$ This would imply some $50 \mathrm{mn}$ people in Africa (mid-1982), excluding the Northern group of states and South Africa. Strictly, the 10-15 per cent refers to adult-equivalents, not 'people'. Undernutrition is concentrated in under-fives; a given caloric shortfall affects them more seriously, and they are themselves concentrated in the poorest households. Hence a 15-20 per cent figure for persons (as opposed to adult-equivalents) at risk of undernutrition would be an appropriate 'safe' upper bound.

${ }^{7}$ See footnote 5 .
} 
maintenance of a good deal of excess body fat. Second, the conversion of these requirements to tropical circumstances and body-weights appears to add further elements of overstatement. Third, individuals may choose below-average lifelong caloric intakes not because they are too poor to do otherwise but because their bodies signal below-average requirements. Fourth, the capacity of any one individual to increase bodily efficiency during temporary periods of moderate dietary shortfall implies that 'average' requirements, per kilogram per day, overstate these requirements during such periods. Finally, where energy intakes really do fall short of requirements, it may be more cost-effective to reduce requirements (for example, by reducing internal parasites that share food with their human hosts; or the long walks needed to fetch distant water) rather than to raise intakes.

The second main line of reasoning is that most careful studies show no lasting damage from states of 'mildto-moderate undernutrition' in under-fives. ${ }^{8}$ Infant and child mortality, in Chen's classic Bangladesh survey, was unaffected; similar results were obtained for subsequent school performance (holding nonnutritional 'social variables' constant) in the equally distinguished Guatemalan (INCAP) work of Klein; and for most indicators of adolescent physical performance, as followed up in the long-term studies of India's National Institute of Nutrition. All these indicators - life chances, school performance, physical capacity - suffered significantly only when child undernutrition was 'severe'.

Third, economic behaviour suggests that perceived priority for extra calories is found only among the poorest 10-15 per cent of persons in low-income countries. When income rises slightly, only these people maintain all three of the following: a) the share, normally $75-85$ per cent, of outlay devoted to food; b) the share of food outlay going to carbohydrate sources; and c) the share of such sources coming from cheap cereals and root crops. The 'poor but not ultrapoor', when income rises, diversify their spending into pleasanter, more varied foods, and into better clothing, shelter, etc.

The operational conclusion to be drawn from these findings is important. The poorest $10-15$ per cent comprise a manageable target for a policy to end undernutrition in Africa in the 1980s, whereas the poorest 45-50 per cent do not. That is the bright side. The dark side is that even agencies such as the World

\footnotetext{
${ }^{8}$ Severe undernutrition implies weight/age ratio below 60 per cent of the 50th percentile on the Harvard scales, height/age ratio below 80 per cent (or 75 per cent on the Gomez version), or weight/height below 70 per cent. Moderate undernutrition: respectively 60-75 per cent; $85-90$ per cent (or 75-85 per cent Gomez); or 70-80 per cent. Mild: respectively 75-90 per cent; $90-95$ per cent (or 85-92.5 per cent Gomez); or 80-90 per cent.
}

Bank, justly proud of their success in redirecting much rural lending towards the poor, bemoan their inability to benefit the poorest decile or two [World Bank 1982b]. Paternalist approaches, such as persuading the 'poorest' to redirect food towards women and children, are unlikely to work. ${ }^{9}$ A review of the handful of Asian projects that have genuinely increased the capacity of the 'poorest' both to produce values and to acquire food may be an important component in any 'food strategy' to reach Africa's neediest. These are projects such as the Employment Guarantee Schemes of some Indian States, or lending to landless artisans by Bangladesh's Gramin Bank.

\section{The Need for Data}

EEC's new approach depends mainly on increased agricultural output, especially of food. To assess the prospects for this, it is necessary to have some idea of how such output and income to buy food has changed in recent years, both in amount and in distribution. It is also desirable to know the amount, timing, and likely prices of major inputs used to grow the main food staples - and, if possible, of alternative crops that might use the resources of land, water, and labour now devoted to those staples.

Our knowledge of the basic facts about staple food production in Africa is negligible as compared with Asia or Latin America. Suppose that the FAO reports an official figure for production $(X)$ of a staple food in an African country in a given year: there are not more than six countries - probably only four - where one can state, with a better than 95 per cent chance of being correct, that true physical output in that year lay between 75 and 125 per cent of $X$. In the case of meat and dairy output from traditional herds, and of food output from smallholdings, an even larger range, say 60-140 per cent of $X$ would probably be more appropriate. We know a little more about the amount (though not the timing) of labour required to produce a given output-per-acre under assorted field conditions in some African countries, provided that only one crop is grown in the field; but of African inputs into the prevailing (and sensible) cultivation of mixed crops, and even more into small traditional herds of 1-10 cattle, we know almost nothing.

Bitty indicators - relative and absolute food prices in free markets, the volume of food imports, the changing incidence of undernutrition in places where income-distribution has apparently changed little do allow us to be fairly confident that in sub-Saharan

\footnotetext{
'African data (unlike North Indian and Bangladeshi studies) show no significant excess of female, child or daughter undernutrition: Schofield [1979]; J. Kreysler and C. Schlage, 'The nutrition situation in the Pangani basin', and R. Korte, 'The nutritional and health status of the Mwea-Tebare irrigation settlement' in Kraut and Cremer [1969].
} 
Africa both food output per person, and to a lesser extent food availability per person, have declined considerably (by somewhere between 5 and 15 per cent) as between comparable years in the late 1960s and in the early $1980 \mathrm{~s} .{ }^{10}$ However, our profound ignorance of the most basic facts of African farm activity militates severely against sensible strategy-building. Countrywide crop-cutting sample surveys have been carried out in most South Asian nations for 30 years or more; in vast areas of Africa, 20 or more years after independence, agro-ignorance prevails, despite endless talk about agriculture, and substantial production of national 'income' data and complex models based on them. Of course, mixed cropping, root crops, and transhumant herding mean that cereal and pulse cropcuts cannot tell us all we need to know. But our ignorance of what the great mass of small, settled African cultivators and herders do, and of how much they produce by doing it, is surely a relatively easily remediable barrier to effective rural policy-making.

Suppose a significant part - say 5-10 per cent - of the aid and technical assistance to African agriculture were used, for five years, to set up and train indigenous capacity to supervise and check the regular and scientific collection of timed, sample data on each season's inputs and outputs, for cereal and root crops (including mixes) and for animals, across the range of major products, conditions, and sizes of farm operation. By 1988 the African nations could have, at last, a sound basis for future agricultural policymaking. Of course, the hungry cannot (and need not) wait until the facts are known. But certainly an EEC food strategy should give high priority, not to a oncefor-all exercise in census-type fact-finding curiosity, but to helping the selected ACP countries to design regular, efficient agricultural statistical services able to collect typical, reliable farm data on a regular basis. Such services should not be lavish or grandiose, but must have proper career structures, and access to policymakers. Agricultural statisticians must not be second-class citizens in a statistical service giving pride of place to national accounts, which mean little if the agricultural data are unreliable. ${ }^{11}$

\footnotetext{
${ }^{10}$ The rapid rise in food imports per person accounts for the smaller decline in food availability.

"Even less explicably, the EEC also lacks the data to assess its contribution to a trade-based (as opposed to a food-productionbased) strategy to reduce undernutrition. For example, the EEC's changing share in the trade of individual or grouped developing countries ( $A C P$ or other) is invariably presented in value terms. This begs the crucial policy questions: was the change due to changes in relative volumes of EEC and 'rest-of-the-world' trade with the relevant partner(s) - or to changes in relative prices? In either case, was it supply, demand, or both that moved differently for EEC and for other trading partners of the Third World?
}

\section{Which Approach to Take}

Let us assume that the development of a 'food strategy' is directed mainly at the dangerously undernourished 10-15 per cent of persons, and that it is supported by a rapidly improving base of production data. What are the main thrusts of such a strategy likely to be? Of course the answers will differ according to the prospects of each country - and its problems. In one or two African countries, priceincentives are so horrendously distorted that little can be done until they are adjusted. In almost all, much more than in Asia or Latin America, the role of agriculture as a milch cow (to support a dubiously productive urban elite, in both public and private sectors) produces price distortions that harm efficiency and equity alike. ${ }^{12}$ Nevertheless, there are grounds to question the concentration on priceincentives of some proposed strategies for African agricultural development, although not, as yet, the EEC's. Better incentives (if we can define them, which may need much better production data) can't be bad; African farmers are just as responsive to price stimuli as other farmers. ${ }^{13}$ However, major diversion of scarce strategy-building energies into efforts to improve price policy, especially if they can be portrayed or caricatured as foreign interference, is probably seldom the best use of those energies in African agriculture, for three reasons.

First, the response of total farm output to priceincentives, while positive, is far smaller than for any particular crop, because land or labour input must be increased and not merely switched between uses. Second, with technology so undeveloped, even substantial price-responsiveness, raising some farmers' outputs by 20 or 30 per cent, would add little to production: 20 per cent of very little is very little. Third, while price-incentives to increase output are sensible for each country taken separately, they could disastrously glut markets of some (mainly export) crops for all African countries taken together.

Generally more important than price policies are measures to make readily available timely inputs (seed, fertiliser), good administrative and technical personnel, and, increasingly, appropriate capital such as small-scale irrigation or drainage. Even where amply staffed, African ministries of agriculture are frequently over-centralised, and hampered by lack of vehicles, petrol, and appropriate incentives to officials from reaching the field. A few unsuccessful, wellpublicised, large-scale and administratively complex

\footnotetext{
${ }^{12}$ The ratio of non-farm to farm output (and income) per person in early modern development in nine now-developed countries was around $1 \frac{1}{2}-2 \frac{1}{2}: 1$. In the $1960 \mathrm{~s}$, in Asia and Latin America it was 3-3 $\frac{1}{2}: 1$ - but in Africa, typically, it is at least 5:1 [Lipton 1977: 435-7].

${ }^{13}$ This was already clear from Dean [1966], esp. ch. 4.
} 


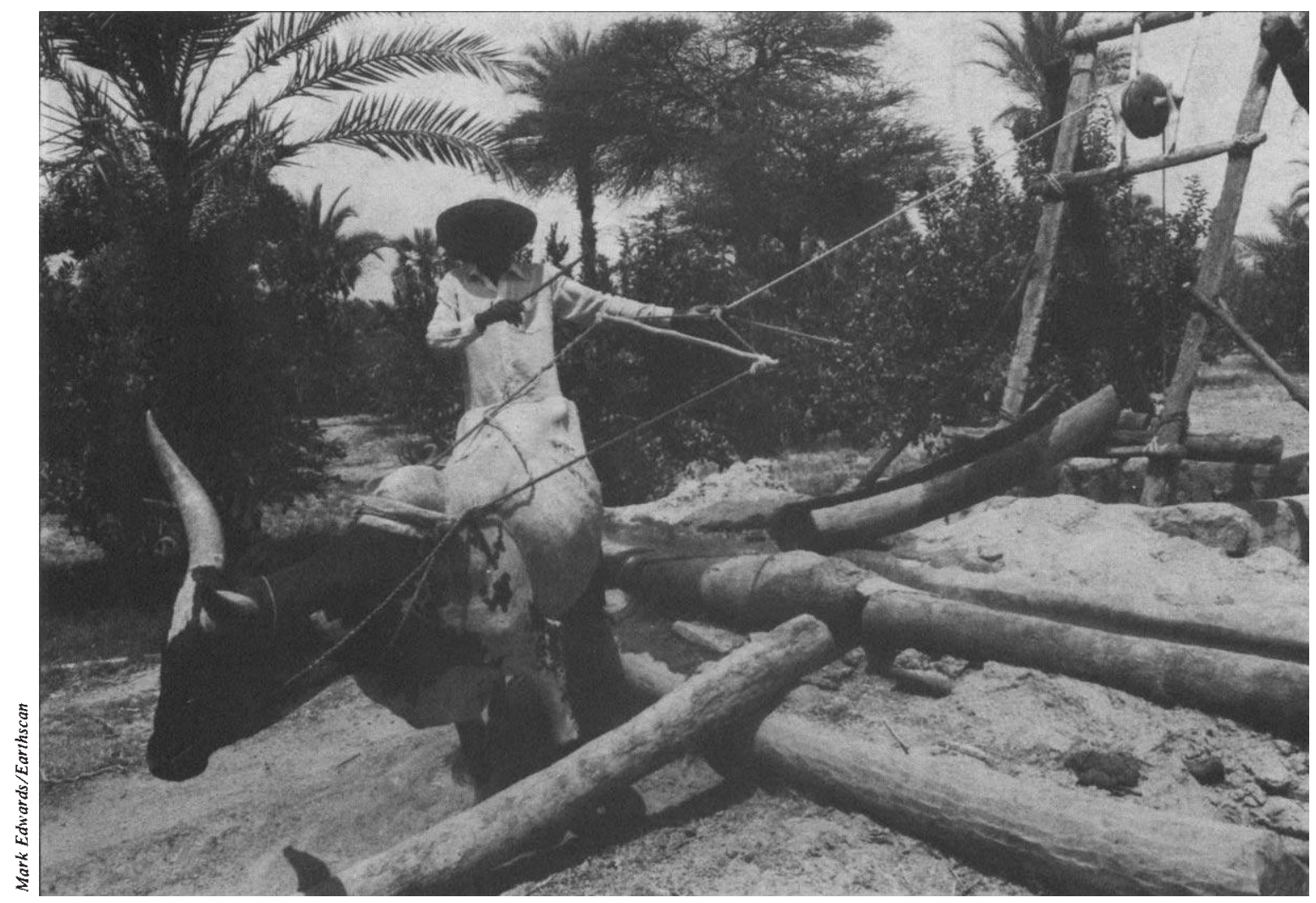

Traditional irrigation in Niger: animal-powered lift irrigation, very common in Asia, is rare (and often in dire need of technical improvements in sub-Saharan Africa.

gravity flow systems have unduly turned opinion against irrigation, even including small lift systems.

However, the most important component of any food strategy, in almost all African countries, will be the development and delivery of technically valid, economically field-tested recommendations and/or new inputs - applied research and its extension. A few outstanding research stations (mostly international) and a few thousand 'modern' farmers (mostly profitable only because of successful angling for highly selective subsidy amid a generally mulcted agriculture) have concealed from many observers the appalling void that fills the huge African spaces where applicable knowledge and scientific smallholding should be. Major crops such as maize, millet and sorghum are broadcast randomly, seldom weeded, denied water management, and hardly ever manured on African smallholdings; as a result they commonly yield at below half the levels prevailing in similar circumstances in Asia. ${ }^{14}$ Neither African farmers nor the much-maligned extension workers are to blame.

\footnotetext{
${ }^{14}$ That is, with similar (and similarly risky) environments, and roughly similar relative prices of inputs and outputs.
}

Little that is useful comes out of the extension pipeline, but this is largely the result of the technocratic nature of most research. Thus, farmers are regularly advised to change planting dates or to apply large amounts of, often remote, kraal manure. To follow such advice has, at best, been proved technically successful at the research station; seldom is it profitable; and hardly ever has it been tested, for profitability and reliability, under smallholders' actual field conditions. Often in disillusionment and doubt, extension workers pass on such advice; farmers accept, or more often reject, it at their peril. The fault lies with frequently irrelevant, sometimes self-serving research.

Fortunately the major advances of smallholderresponsive techno-economic research in Asia and Latin America have provided a large backlog of ideas for food crops: high-yielding varieties, timings, spacings, crop-mixes, planting and soil-enriching methods, water uses, and much more. These ideas are waiting to be tested and adapted to various local conditions in Africa. The long lags associated with the initial application of basic research need not prevail in 


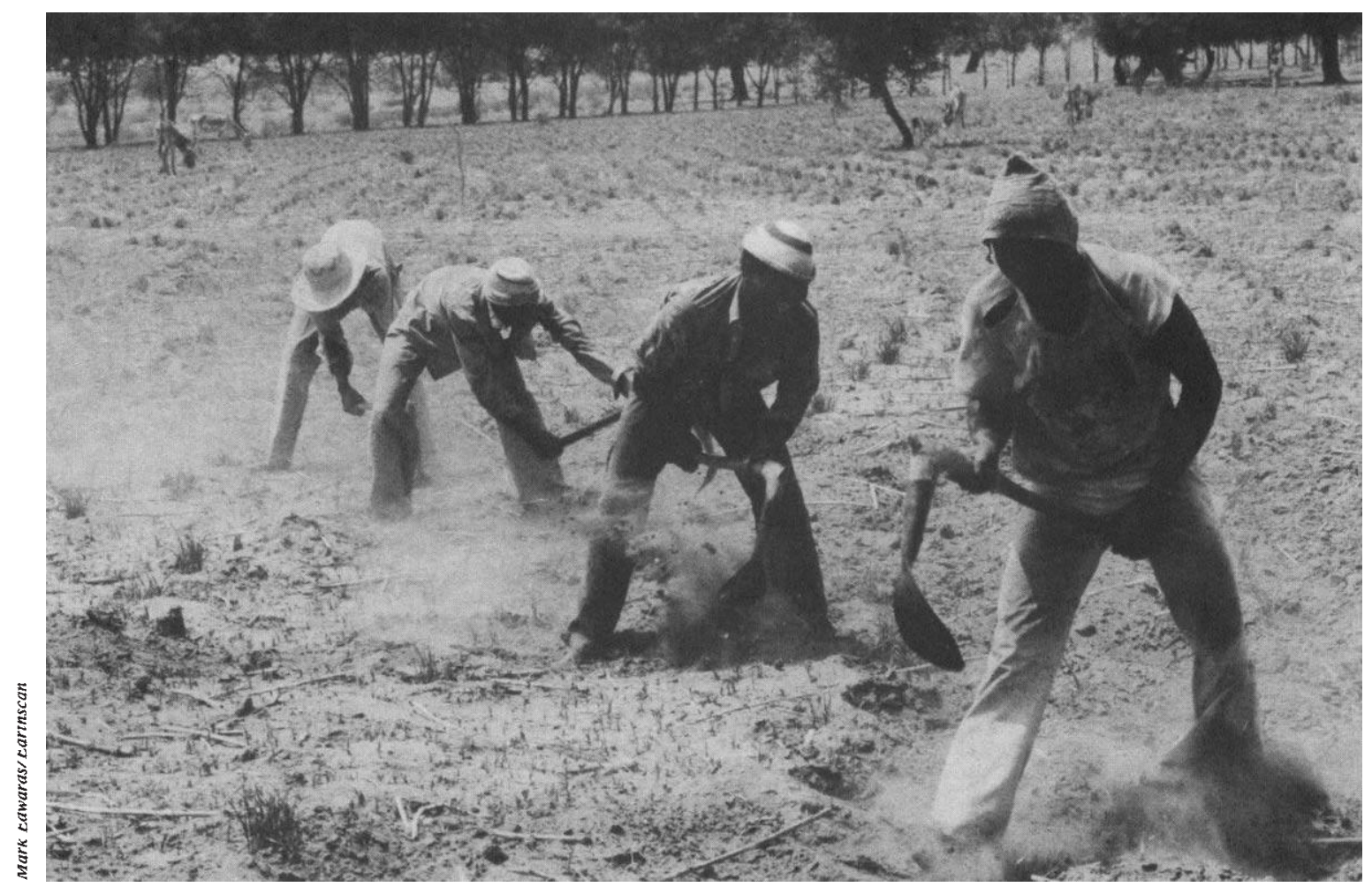

Rows of trees provide wind-breaks against erosion in Niger; but is erosion increased by traditional hoeing on hard soils and unmixed cropping?

Africa. What is needed are career structures and 'tied' funds to help African governments ensure that farming research is rewarded if, and only if, it benefits farmers, especially poor food-cultivators and herders.

If this is done, a research-based, EEC-backed 'food strategy' could do what a hectoring 'policy dialogue' cannot: persuade and help recipients to 'get the prices right', and to increase resource allocations to agriculture, by leading into a virtuous circle. If yields are only $50-200 \mathrm{~kg}$ per acre, as is now typically the case in much of Africa, the cost to government of discouraging farm output by food price policies or public resource allocations that appease urban interests, seems relatively small. But if, for example, the grain yields, foregone through inadequate incentives or fertiliser delivery systems, have been raised by researçh to 2-3 tons per acre, attainable profitably by smallholders at acceptably low risk, the costs of neglect are clear to government. Without a research push - and a smallholder, food-linked, fieldtest-oriented research strategy - good intentions with regard to prices and allocations for African agriculture are likely to be frustrated.
Similar principles, of centring easily rural development around technologies that make sense for poor people who own little but their labour-power, apply to the artisan 'surround' of agriculture. Economists who get to know African villages after experience in Asia or Latin America are astounded by the apparent relative absence of sophisticated but labour-intensive technology - not only in agriculture (row planting, waterwheels, rotary weeding) but also in artisanship. The two absences, indeed, are linked. Without a plane, a vice, a saw, a workbench, and a few taught principles, a carpenter can scarcely produce a seed-drill, an appropriate plough, a water-wheel. A blacksmith without a bellows is analogously handicapped, whatever his skill in adapting parts from abandoned cars. Moreover, an unproductive rural 'surround' cannot afford to demand much food from local farmers, just as it cannot supply them with much of the wherewithal to grow or process it.

\section{Labour or Capital}

To base a food strategy on rapid adaptive research into such 'poor people's technology' is, in a sense, to 


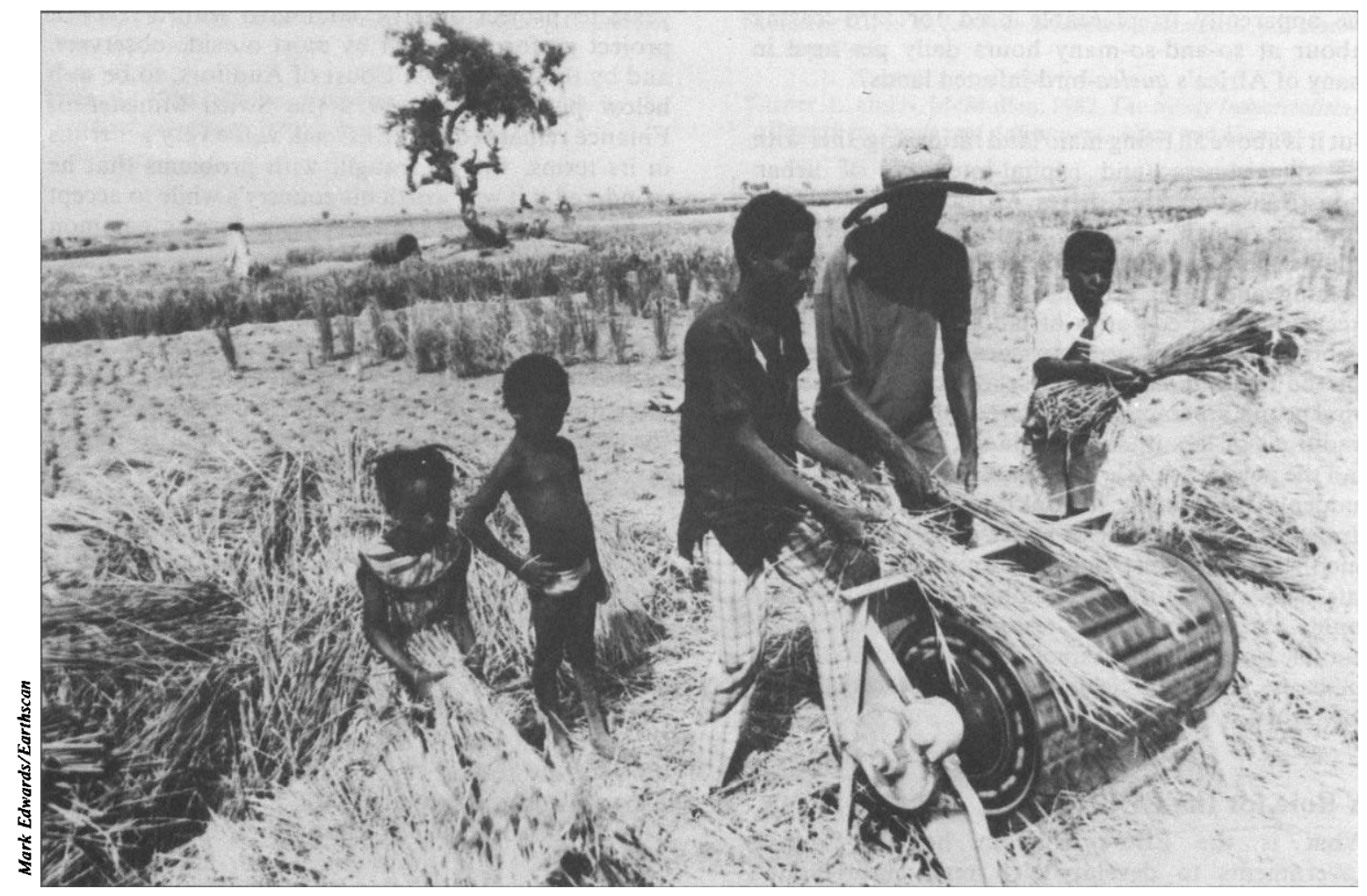

Mini-thresher, Niger: will this raise output or just displace workers?

learn from Asia. However, it might be objected that in Asia even such innovations as high-yielding cereals have probably benefited the rural rich more than the rural poor, even though they supply cheap calories, are labour-intensive, and tend to reduce risk. ${ }^{15}$ By most Asian standards, however, Africa's greater ruralurban inequality and intra-rural equality increase both the urgency of the proposed research strategy and its prospects of an equitable outcome.

A deeper objection is that most of Africa, unlike most of South and East Asia, appears to have no land shortage. Hence labour-intensive strategies of smallfarm crop production are not so obviously indicated. Why not a strategy of big farms, capital-intensity in crop production, and extensive animal grazing? Merely to intone 'small is beautiful', or to treat employment (i.e. drudgery) as an end in itself, is not to dispose of this alternative strategy, which has lasting

\footnotetext{
${ }^{15}$ The poor have not lost absolutely; would have been far worse off without the extra food grown due to HYVs; and must have gained from the technology's impact in raising labour/land ratios and in providing 'inferior goods'. But the rich gained proportionately more [Lipton 1979a, 1978].
}

appeal for many African politicians and bureaucr Big farms seem 'modern' and scientific; small far seem random and messy.

However, the appearance is illusory since it is crea by subsidies (on credit, fuels, etc) enjoyed only by farms, and by ignorance of the complex economic small farms. Population pressure is rendering Afric agricultures every day more like Asia's. Land is gett scarcer and dearer; techniques from stall-feed through row-planting to composting are becom increasingly attractive with the growing pressure workers on scarce land and capital. All this rendering small farmers, who choose higher ratio workers to land and to capital, relatively $\mathrm{m}$ efficient and big ones less so. Moreover, even wh good land is genuinely plentiful, it may be costly bring into cultivation or, once cleared, restricted cultivation at existing yields by available labo Suppose that a tractor could, in principle, ena families to farm more land; could yields per acre existing levels of water and manure use and of $s$ varieties, pay for the tractor's costs? Again, is intensive, rather than extensive, farming indicated 
the apparently irreplaceable need for bird-scaring labour at so-and-so-many hours daily per acre in many of Africa's quelea-bird-infested lands?

But it is above all rising man/land ratios, together with the sluggishness (and capital-intensity) of urban industrialisation, that drives African food strategies towards 'Asian', labour-intensive, and therefore small-scale technologies and research guidelines, in farming and rural artisanship alike [Lipton 1979]. Accustomed to centuries of labour shortage and of plentiful arable land, and to decades of propaganda for the big and shiny and pseudo-modern, African rural people are trapped between equally inappropriate traditions of labour-saving: the old (slash-and-burn) and the new (tractors). They cannot be expected to be suddenly enthusiastic for unknown labour-intensive strategies, row-planting or water-wheels or whatever. Such strategies must first be proved profitable and safe. This will require their combination with scientific inputs through adaptive research to select locally suitable water techniques, soil-enriching additives and methods, and high-yielding varieties of cereals and root crops.

\section{A Role for the EEC}

What is the EEC's role in helping African governments to develop such research-orientated strategies for high-income, low-risk, labour-intensive small farming? Three aspects of the EEC's approach to the relationship with Africa will need fairly drastic attention if such strategies are, in fact, to emerge from Commissioner Pisani's initiative. They are the management of the project cycle, the overview of country programming, and the impact of EEC's own trade policies.

The project cycle comprises five stages: identification, design and appraisal, approval, implementation, and monitoring and evaluation. It would, I suppose, be fairly widely agreed in the 'aid business', as well as in the relevant academic disciplines, that there are fairly deep problems about the European Development Fund's (EDF) project cycle, for aid to Lomé Convention states. The long delays in disbursing agreed funds, especially for the 'new' (1975!) Associates, are the most obvious but not the most alarming sign of this. Others are the frequency of EDF-linked impediments in co-financed projects, even if the EDF finances only a small part of them; the fact that, much more than with other aid agencies, the rise in the rural proportion of aid - the 'shift towards rural development' - in the data often turns out, on the ground, to correspond to buildings, roads, or other hardware with little benefit to rural people, especially the poor; and the very large ratio of 'technical assistance' (costing about $\$ 120,000$ per professional- year) to project outlays, combined with a level of project performance felt by most outside observers, and by the EEC's own Court of Auditors, to be well below par. When in 1979 the Swazi Minister of Finance remarked that EEC aid, while very generous in its terms, was so fraught with problems that he wondered if it was worth his country's while to accept it, he merely expressed in extreme form a common sentiment. What is going wrong?

As regards project identification, EEC's possession of a 'delegate [in each ACP country] who deals exclusively with aid' should place EDF in a specially advantaged group of aid funds. ${ }^{16}$ In practice, however, the delegate's capacity in project administration is severely constrained.

As regards appraisal, recipient countries do not seem to feel that they know enough to decide whether a particular project is likely to be appraised favourably. 'In the negotiations for Lomé II, [ACP] suggested that a checklist of criteria used in appraisal should be communicated' [White 1981:55], i.e. not even a checklist was available during the first four EDFs, and even now no formal appraisal rules (i.e. weights to indicate the relative importance of checklist items) appear to be available to ACP national authorities. This is bound to be especially troublesome for agricultural, and even more for wider ruraldevelopment, projects, because their justification is especially likely to depend on the relative weights attached to different types of expected returns: financial, economic (i.e. allowing for price 'distortions' and for costs and benefits outside the project's immediate range of application), and social (i.e. allowing, in a stated way, for the distribution of gains and losses from the project).

As regards approval, the EDF gains because it has simple procedures for small and emergency projects, and separate funds to pay for them. But it loses, at least in theory, because the techno-economic judgements of the aid agency (effectively DG 8) are not the last word in approving or rejecting a project. Projects also have to be referred to an international committee, the 'EDF Committee', on which all 10 EEC members are represented. The precise distribution of responsibility between DG 8 and the EDF committee is a shadowy area, and DG 8 is jealous of its formal power. Nevertheless, the need to get the approval of 10 nationalistic, heterogeneous donors must cast a long shadow. It must, that is, constrain the design of projects that EDF delegates can recommend ACP governments to identify, or can themselves appraise favourably. The rising share of rural development projects in EDF4 and EDF5 plainly

\footnotetext{
${ }^{16}$ Only France and the USA appear to have similar non-embassy, field missions for aid in most recipient ldes [White 1981].
} 
owes something to EEC enlargement in 1973, by two countries relatively heavily committed to such projects, Denmark (via DANIDA) and the UK (since the 1975 White Paper, Changing emphasis in British aid policies: more aid for the poorest).

As the tide of support for poverty-orientation gives way to the new wave of mean monetarism, associated with the promotion of inefficient exports through aid, the Commission and EDF may find donor readiness to approve rural development projects eroded. DG 8 itself is fighting such trends, as M. Pisani's memorandum indicates, but its unenthusiastic reception by donor politicians suggests that protectionism, Samuel Smilesery and slump in developed countries will continue to imperil approvals for socially-effective uses of aid. If so, the multilateral politicisation of EEC approval procedures will not help.

After approval comes implementation. Tied procurement, being 'spread' across competing suppliers throughout the EEC, ought to create far fewer problems than when goods and services can be bought only in one, sometimes small and uncompetitive, donor country. Moreover, local costs form a relatively large part of rural development project aid. Hence EEC aid to rural development projects should be less vulnerable to procurement delays than tied bilateral and/or non-rural aid.

Finally come monitoring and evaluation. Much attention is drawn, from time to time, to public and detailed blasts at completed (or stymied) rural and other projects from the EEC's Court of Auditors. The impression is given by these reports that EEC aid is managed openly, self-critically and responsively. The independent, unbureaucratic and frank approach of the Auditors is indeed praiseworthy; many bilateral donors, notably the UK, would also benefit if evaluation were handled independently of the aid agency. Unfortunately, while the Auditors' legal and accounting expertise is useful in detecting graft or incompetence, it is of little value in establishing the vital facts sought by project evaluation: the economic (not financial) rate of return on project outlays, and the distribution of costs and benefits between rich and poor, urban and rural, men and women, old and young. Moreover, brief visits to a problem project, however sensational their outcomes, cannot replace socio-economic evaluation, in operation as well as immediately after completion, of at least a substantial random sample of projects. Only the World Bank and USAID, so far as I know, do this systematically. Lack of evaluation - let alone of a 'lesson-learning' mechanism, an institutional memory for moving from past evaluations to new designs - is especially damaging in rural development, with its relatively great need for cross-ministry integration, its recent expansion, and its high proportion of costs devoted to non-standardised, often local, software.

EEC aid suffers from being neither bilateral nor multilateral, neither centralised nor decentralised. At each stage of the cycle, projects appear therefore to go through three sets of hoops, in turn supplied by delegates, local Commission institutions, and national donor politics. Rural projects, which are less responsive to (and less dependent on) standardised hardware and which have recently expanded their share in the EDF portfolio, are especially vulnerable to the resulting problems, encompassing not only project aid but also food aid.

The facts remain that Africa's increasing net food imports are its central development constraint; that growing hunger is its central poverty problem; and that EEC is well placed to help, and in the medium term to gain by so doing. However, the project cycle, and the underlying problem of country programming, will need attention, if this potential is to be realised.

If the EEC is to use its relationship with ACP to help individual African countries to implement their food strategies, then the EDF's project cycle will need to be coordinated, at a level permitting unified support of a recipient nation's food strategy, with EEC's own food aid, and possibly (though this presents a major problem) with bilateral aid from major EEC donors. Finally, EEC's aid policies need to be made more consistent with its trade policies, as these affect developing nations' capacity to provide adequate calories for all their people, and to avoid unsustainable levels of food imports. The reorganisation of DG 8 in September 1982 is designed to facilitate such coordination and is therefore to be welcomed. Performance under the new system should be monitored closely to see whether further changes will be necessary.

M. Pisani clearly envisages that food aid, not just the EDF, should support national food strategies [COM (82) 640:final, para 2.2]. Yet food aid today, both in the political reality and in the formal structure of the Commission, is more an upshot of the CAP's surpluses than a part of EEC development policy. In the latter, its main role is to restore regional balance; and the real conflict between this goal, and the coordination of EDF and food aid to support national food strategies, has to be tackled.

EDF's extreme African emphasis owes more to nineteenth-century colonial history, 1957 negotiating practice, and the wishes of a few French firms, than to EEC interests or the requirements of development and poverty-alleviation. In 1960 or even 1970 , the 
incidence of poverty was much more severe in South Asia. If Africa has now overtaken South Asia in the grisly race for the title of hungriest region, it has been the result largely of extreme neglect of agriculture and of poor policy response to the oil crises. Africa has fallen back despite aid-per-person over double South Asian levels since 1960. Prima facie, it looks as if it is techno-economic rural research and nationwide skill development that constrain most African nations' performance in growing, feeding their people, and reducing poverty. It is certainly true that technical assistance is relevant to the alleviation of such constraints, but it is the Asian nations, aid-starved anyway, that really suffer from conventional capital constraints. Normally Africa is the locus of talk about 'shortage of good projects', lack of absorptive capacity, etc. Indeed in the 1960s aid-per-person made a major difference to the growth-rate comparisons in Asia - but not in Africa [Papanek 1972, 1973]. Yet the regional aid disparity is likely to worsen in the 1980s: US aid is becoming more 'strategic' in orientation, i.e. probably less South Asian; the World Bank proposes to double concessional flows to subSaharan Africa in the 1980s, leaving little or nothing for expanded flows to South Asia. ${ }^{17}$

The small, if growing, non-associates' aid budget, of which India is a major beneficiary. has brought a limited but welcome reduction in the EEC's contribution to the anti-Asian bias in world aid flows. EEC food aid has led to far larger reductions in that contribution, since it frees resources for development investment by allowing recipients to cut commercial food imports. Should EEC (even in the interests of food strategies) divert that gain towards Africa, most of which, though absolutely poor and under-aided, is over-aided relatively to the desperate poverty of, say, Bangladesh, Bihar or Java?

Perhaps one remedy is to nominate, fairly soon, one or two interested Asian 'non-associates' who wish to design a food strategy, for which their food aid and (enhanced?) parts of the non-associates' aid programme could be supportively used. Meanwhile, a substantial minority even of EEC food aid goes to Africa. Its planning and concentration, in ways that support states seeking to develop food strategies (instead of undermining those who seek such strategies, by depressing domestic food prices or by seeming to remove the urgency of investment in food production); is clearly sensible. But it raises problems inside the Commission, both of the rights and powers of different Directorates, and of the realpolitik of European agriculture; for example, the issue of 'grain versus grazing' as encouraged by the balance of EEC farm subsidies cannot be immune, if DG 8 is allowed

\footnotetext{
${ }^{17}$ Given a) the difficulties of IDA replenishment; b) new claims for China.
}

to influence surplus disposal (and ultimately surplus build-up) by adducing issues such as food strategy for ACP nations.

M. Pisani has sometimes suggested that he hopes to coordinate in support of ACP national food strategies, not just EEC project and food aid, but also EEC members' bilateral programmes [Stevens 1983, ch. 13]. However, the EDF now absorbs only 10 per cent of EEC members' capital aid. Even that 10 per cent is unpopular with several powerful member states. The reasons are partly that bilateral aid is better than multilateral aid for promoting sales of overpriced donor exports, and for beating the nationalist drum; but there are better reasons, too. EEC aid is seen as having high administrative costs, little parliamentary control, and severe management problems. Both $\mathbf{M}$. Cheysson and $M$. Pisani have tried to tackle these issues; but major successes are probably required before there can be much chance of harnessing bilateral programmes to Brussels-designed support from EEC for national food strategies. A useful start could be made by improving the links between explicitly food-orientated components of bilateral and EEC aid programmes.

A final question concerns the linkage of EEC trade and production policies to its support of African food strategies. Even more than food aid, such policies are at present firmly outside DG 8's sphere of influence. Yet in at least two areas, sugar and vegetable oils, the side-effects of the CAP damage the incomes of poor farmers in developing countries and therefore their capacity to buy food (or to pay for investments in its production). African and other Associates do not escape the impact (over a third of Associates' sugar exports are currently sold at world prices, depressed by the EEC's de facto dumping). Special arrangements for African beef exports, while generous and welcome in isolation, can shift farm resources away from small farmers growing cheap (i.e. usually cereal or root) calories for local consumption. On the borderline between aid and trade is Stabex; the significance of its benefits has been questioned in an excellent recent analysis [Hewitt 1983], but its net effect has to be to shift ACP governments, and indirectly farmers, away from food production for home use, and towards commodities sold to EEC with some degree of apparent stability of earnings.

The EEC's food strategy, especially in combination with parallel approaches in other aid agencies (such as Sweden's, and IFAD), could be a major advance in developing a coherent, locally-specific set of strategies to tackle the central problem of poverty in Africa. This article has argued that, to succeed, such an approach will require a) concentration upon groups at major nutritional risk - groups that are smaller but also 
rather harder to reach than is usually claimed; b) a systematic prior effort to generate regular national procedures to gather reliable farm output, and to some extent input, data; c) an approach to developing agriculture and the rural surround that is based on techno-economic research and its delivery embodied in field-tested, attractive inputs - not on 'pushing a piece of string' by seeking to develop agriculture via incentives or institutions based on the present technoeconomic darkness; d) some 'learning from Asia' in respect of technology and farm-size policies; and e) the resolution of critical questions about the procedures and powers of EEC itself, in respect both of the project cycle and of the political context of Third World policies These problems are raised in this article, not to denigrate the 'food strategy' approach, but - by outlining some major problems in making it into a reality - to improve, however slightly, its chances of success.

A version of this article is being simultaneously published in the ODI Development Policy Review.

\section{References}

COM (82) 640, Memorandum on the Community's Development Policy, The Courier no 76, Nov-Dec

Dean, E., 1966, The Supply Response of African Farmers, North-Holland, Amsterdam

Hewitt, A., 1983, in C. Stevens (ed), EEC and the Third World: a Survey 3: The Atlantic Rift, Hodder \& Stoughton for ODI/IDS, London

Kraut, H. and H.-D. Cremer (eds), 1969. Investigations into Health and Nutrition in East Africa, Weltforum-Verlag, Munich
Lipton, M., 1977, Why Poor People Stay Poor, Temple Smith, London

-1978, 'Inter-farm, inter-regional and farm-nonfarm income distribution: the impact of the new cereal varieties', World Development, vol 6 no 3

-1979a, 'The technology, the system, and the poor: the case of the new cereal varieties', in Institute of Social Studies, Developing Societies: the Next 25 Years, Nijhoff, The Hague

-1979b, 'African agriculture and Asian experience: the case of Botswana', Institute of Development Management, Gaborone, mimeo

OAU, 1981, Lagos Plan of Action for the Economic Development of Africa: 1980-2000, International Institute for Labour Studies (Switzerland) for Organisation of African Unity

Papanek, G., 1972, 'The effect of aid and other resource transfers on savings and growth in less developed countries', Economic Journal, 82, September

-1973, 'Aid, foreign private investment, savings and growth in Idcs', Journal of Political Economy, 1

Prebisch, Raoul, 1959, 'Commercial policy in the underdeveloped countries', American Economic Review (Papers and Proceedings), May

-1964, Towards a New Trade Policy for Development, report by the Secretary-General of UNCTAD, UN

Schofield, S., 1979, Development and the Problems of Village Nutrition, Croom Helm, London

Stevens, C., 1983, EEC and the Third World: a Survey 3: The Atlantic Rift, Hodder \& Stoughton for ODI/IDS, London

White, J., 1981, Compendium of Aid Procedures, OECD, Paris

World Bank, 1982a, Accelerated Development in sub-Saharan Africa, Washington DC

-1982b, Focus on Poverty, Washington DC

- 1983, 'Poverty, undernutrition and hunger', Staff Working Paper (by M. Lipton) 